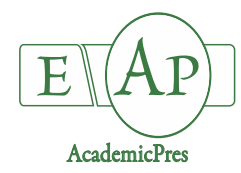

Alzahrani Y et al. $(2020)$
Notulae Botanicae Horti Agrobotanici Cluj-Napoca 48(2):906-923
DOI: $10.15835 /$ nbha48211909
Research Article

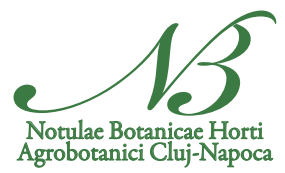

\title{
Modulating effect of EDTA and SDS on growth, biochemical parameters and antioxidant defense system of Dablia variabilis grown under cadmium and lead-induced stress
}

\author{
Yahya ALZAHRANI, Hesham F. ALHARBY*, Khalid R. HAKEEM*, \\ Hameed ALSAMADANY
}

\author{
King Abdulaziz University, Faculty of Science, Department of Biological Sciences, Jeddah, \\ SaudiArabia; khakim@kau.edu.sa; kur.hakeem@gmail.com; halharby@kau.edu.sa (*correspondingauthor)
}

\begin{abstract}
The present study investigated the influence of inorganic amendments viz., SDS (sodium dodecyl sulphate) and ethylenediaminetetraacetic acid (EDTA) in enhancing metal tolerance in plants. Seedlings of an important ornamental plant, Dablia variabilis Cav. were grown under cadmium $(\mathrm{Cd})$ and lead $(\mathrm{Pb})$ stress. 30days old seedlings were transferred to pots containing sterilized sand and supplemented with Hoagland's medium. After 15 days of transplanting, four treatments $\left(0,10,25\right.$, and $\left.100 \mathrm{mg} \mathrm{kg}^{-1}\right)$ of Cd and four treatments of $\mathrm{Pb}\left(0,100,500\right.$ and $\left.5000 \mathrm{mg} \mathrm{kg}^{-1}\right)$ were used with or without application of $2.0 \mathrm{mM}$ SDS and $2.5 \mathrm{mM}$ EDTA, separately and in combination. Seedlings were further grown for 60 days in culture media. Results revealed that both $\mathrm{Cd}$ and $\mathrm{Pb}$ significantly reduced plant growth, pigment content, and relative water content. Antioxidant enzymes viz., superoxide dismutase (SOD), peroxidase (POD), ascorbate peroxidase (APX), and catalase (CAT) along with protein and total soluble sugar contents showed a declining trend with an increase in $\mathrm{Cd}$ and $\mathrm{Pb}$ concentrations applied. The $\mathrm{Cd}$ and $\mathrm{Pb}$ treatment enhanced the production rate of reactive oxygen species (ROS) as depicted by the increased malondialdehyde (MDA) and hydrogen peroxide $\left(\mathrm{H}_{2} \mathrm{O}_{2}\right)$ production in leaf. Inorganic amendments viz., EDTA+SDS applied either alone or in combination significantly alleviated $\mathrm{Cd}$ and $\mathrm{Pb}$-induced toxic effects. However, a combination of EDTA+SDS showed significant results than used separately. These results revealed that the application of inorganic amendments in combination can enhance the phytoextraction capacity of the species studied. However, the effects of various amendments vary with the nature of the inorganic compound. The study suggests that the application of EDTA and SDS could be a useful strategy for enhancing the phytoextraction capability of Dablia variabilis to remove $\mathrm{Cd}$ and $\mathrm{Pb}$ from contaminated soils.
\end{abstract}

Keywords: assisted phytoremediation; cadmium; phytoremediation enhancers; phytoremediation; ROS 


\section{Introduction}

The soil is a non-renewable natural source, which is contaminated by heavy metals (HM) coming from different sources viz., waste from smelters, mines, atmospheric deposition, drainage, inorganic fertilizers and other anthropogenic activities (Singh and Kalamdhad, 2011; Pirzadah et al., 2014). These HMs combine with living molecules within the body of an organism, such as proteins and metabolites, to form various toxic biological compounds that hamper the normal functioning of the cellular machinery (Duruibe et al., 2007; Anjum et al., 2014, 2015; Ghori et al., 2019). HM pollution also affects agricultural productivity and causes various diseases in humans such as cancer, brain disorder, gastrointestinal problems etc. (Ozturk et al., 1989; Duruibe et al., 2007; Jaishankar et al., 2014; Hakeem et al., 2015). Cadmium (Cd) and lead (Pb) and are the two most common HMs that are highly toxic to plants as well as humans (Qureshi et al., 2007; Gallego et al., 2012; Rizwan et al., 2016; Saifullah et al., 2016).

Establishing a low cost and eco-friendly remediation plan to decontaminate these HMs from the soil is highly desirable. Many technical methods have been investigated and tried to remediate the contaminated soil viz., cover system, soil washing, stabilization, thermal treatment and disposal landfill (Sabir et al., 2015a; Sarwar et al., 2017). However, phytoremediation is an effective, eco-friendly, low cost and easier technique to clean up the soil from HM contamination (Jabeen et al., 2009; Pirzadah et al., 2014; Saxena et al., 2019). It was observed that large amounts of toxic substances could accumulate in the leaves and stems of many plants without hindering their normal functioning, depending on plant species and environmental factors (Ehsan et al., 2014; Iqbal et al., 2015; Ozturk et al., 2015a,b ). Many plant species, known as hyperaccumulators, are used as the viable candidates for performing phytoremediation. Ornamental plants are also known to behave as good phytoremediation agents in HM-contaminated soils (Szczygłowskan et al., 2011; Pirzadah et al., 2014). The idea of using ornamental plants as the candidates of phytoremediation could be economically viable, as they could also serve to boost the local floriculture industry and beautify the land filled with heavy metal pollutants.

While the accomplishments of phytoremediation technique are growing, still various factors such as the complexity, $\mathrm{pH}$, chemical nature and ion-exchange capacity of soil particles, are limiting its application (Quartacci et al., 2000; Aziz et al., 2016). The use of chemical enhancers of phytoremediation is nowadays gaining high attention (Farid et al., 2013; Pirzadah et al., 2014; Hasan et al., 2019). Various chelating agents have been used for the remediation of heavy metals. Ethylenediaminetetraacetic acid (EDTA), sodium dodecyl sulphate (SDS), ethylene gluataro tetraacetic acid (EGTA) are a few significant chelating agents to sequester the toxicity of $\mathrm{Cu}, \mathrm{Cd}$ and other heavy metals (Bareen 2012; Chigbo and Batty, 2013; Kambhampati, 2013; Mani et al., 2014). The chemical amendment-induced remediation of heavy metals by plant species is an effective technique because it has high binding capacities toward the majority of the heavy metals (Hasan et al., 2019). However, the combination effects of these chelating inorganic molecules have not been comprehensively investigated, particularly in ornamental plants.

To fill this void, the present study was conducted to determine the enhancing role of EDTA and SDSon the Dablia variabilis growth, biochemical parameters and antioxidant defense system, besides determining its phytoextraction capability and tolerance index against $\mathrm{Cd}$ and $\mathrm{Pb}$. This study should be helpful in understanding the role and mechanism of enhancing phytoextraction capabilities of the ornamental plants against under $\mathrm{Cd}$ and $\mathrm{Pb}$ stress.

\section{Materials and Methods}

\section{Plant material and growth conditions}

Healthy seeds of Dablia variabilis were procured from the Department of Biological Sciences, King Abdulaziz University, Jeddah, Saudi Arabia, thoroughly washed first with tap water and then with distilled 
water to remove the debris, and then sown in egg trays containing $5.08 \mathrm{~cm}^{3}$ axenic sand. The whole experiment was conducted under the environmental controlled conditions (in a greenhouse under randomized completely block design with three replications. The pots were filled up with sandy soil and were kept under greenhousecontrolled conditions light/dark regime about $12 / 12 \mathrm{~h}$, at $25 / 15 \pm 3^{\circ} \mathrm{C}$ and relative humidity (RH) $30-50 \%$, respectively) during November 2017. After 3 weeks, the healthy uniform seedlings were transferred to pots. Hoagland's nutrient solution (Hoagland and Arnon, 1950) containing $\mathrm{KNO}_{3}, 10.11 ; \mathrm{K}_{2} \mathrm{SO}_{4}, 9.75$; $\mathrm{MnCl}_{2} .4 \mathrm{H}_{2} \mathrm{O}, 0.0178 ; \mathrm{MgSO}_{4} .7 \mathrm{H}_{2} \mathrm{O}, 2.218 ; \mathrm{FeSO}_{4}, 0.05 ; \mathrm{EDTA}, 0.075 ; \mathrm{NaH}_{2} \mathrm{PO}_{4}, 1.404 ; \mathrm{CaSO}_{4}, 0.17$; $\mathrm{H}_{3} \mathrm{BO}_{3}, 0.014 ; \mathrm{ZnSO}_{4}, 7 \mathrm{H}_{2} \mathrm{O}, 0.01 ; \mathrm{CuSO}_{4}, 7 \mathrm{H}_{2} \mathrm{O}, 0.002$ and $\mathrm{NaMoO}_{4} .2 \mathrm{H}_{2} \mathrm{O}, 0.000725$ (all in g/ $100 \mathrm{ml}$ )was applied to plants and revived after every 7 days interval until the plants were harvested. $\mathrm{Cd}$ concentrations (from the cadmium salt $\mathrm{CdCl}_{2}$ ) ( $0=\mathrm{Control}, \mathrm{Cd} 1=10, \mathrm{Cd} 2=25$, and $\mathrm{Cd} 3=100 \mathrm{mg} \mathrm{kg}^{-1}$ and $\mathrm{Pb}$ concentrations (from the $\mathrm{Pb}$ salt $\left.\mathrm{PbCl}_{2}\right)\left(0=\right.$ Control, $\mathrm{Pb} 1=500, \mathrm{~Pb} 2=1000$, and $\left.\mathrm{Pb} 3=5000 \mathrm{mg} \mathrm{kg}^{-1}\right)$ were applied in pot with chemical amendments along with the Hoagland solution (2.5 mM EDTA+ $2 \mathrm{mM}$ SDS designated as E 1,2.5 mM EDTA, designated as E2 and $2 \mathrm{mM}$ SDS designated as E3). The plants were harvested after the 2 months.

\section{Morphological parameters}

Morphological traits such as as the height of the plant, number of leaves, internode distance and fresh mass, were determined from ten seedlings. Biomass accumulation was quantified after processing the plant following the protocol of Qureshi et al. (2005). The remaining harvested leaf samples were kept in sealed vials and immediately frozen in liquid $\mathrm{N}_{2}$ and then stored at $-80^{\circ} \mathrm{C}$ for further analysis.

2.2 Tolerance index (TI) and translocation factor (TF)

The TI was determined according to Wilkins's equation (Wilkins, 1957).

$\mathrm{TI}$ (percentage) $=\mathrm{ML}_{\text {metal }} / \mathrm{ML}_{\text {control }} \times 100$.

$\mathrm{ML}_{\text {metal }}$ and $M \mathrm{LL}_{\mathrm{c}}$ represent the average length of the longest roots of Pb-treated and control seedlings, respectively. TF was calculated by the following equation (Marchiol et al., 2004).

$\mathrm{TF}=$ Metal concentration in shoots/Metal concentration in roots.

\section{Relative water content $(R W C)$}

For determining the RWC, small fresh leaf discs were weighed (FW) and later floated on the deionized water in a petri dish for $8 \mathrm{~h}$ under dark conditions. The surplus water was dried using paper towels and turgid weights (TW)were calculated. Lastly, the samples were kept in the oven for $48 \mathrm{~h}$ at $80^{\circ} \mathrm{C}$ to measure the dry mass. The RWC was measured by using the following equation:

RWC $(\%)=(F W-D W / T W-D W) \times 100$

\section{Chlorophyll content}

For determining the chlorophyll content, $500 \mathrm{mg}$ of leaf sample was taken and homogenized with 10 $\mathrm{mL}$ of acetone $(80 \% \mathrm{v} / \mathrm{v})$. Later the mixture was centrifuged for $10 \mathrm{~min}$ at $5,000 \times \mathrm{g}$ and the supernatant were used to measure the absorbance at 663,645 and $470 \mathrm{~nm}$ respectively, according to Lichtenthaler and Wellburn (1983).

\section{Measurement of $\mathrm{H}_{2} \mathrm{O}_{2}$}

Hydrogen peroxide $\left(\mathrm{H}_{2} \mathrm{O}_{2}\right)$ was determined according to $\mathrm{Yu}$ et al. (2003) and the absorbance was measured at $410 \mathrm{~nm}$ to quantify the concentration of $\mathrm{H}_{2} \mathrm{O}_{2}$ expressed as nanomoles/gram fresh mass.

\section{Measurement of lipid peroxidation}

Lipid peroxidation usually measured in terms of TBARS, chiefly MDA was calculated following the protocol of Heath and Packer (1968) and the concentration of MDA was expressed as nanomoles/gram fresh mass, with molar extinction coefficient as $155 \mathrm{mM}^{-1} \mathrm{~cm}^{-1}$. 


\section{Determination of osmolytes}

Proline concentration was assayed according to Bates et al. (1973) and expressed as $\mu \mathrm{gg}^{-1} \mathrm{FM}$. The total soluble protein was analyzed following the method of Bradford (1976) using Coomassie brilliant blue G-250 as dye and BSA as standard.

\section{Antioxidant enzymes and total soluble protein content}

For enzymatic analysis, both root and leaf samples were ground into powdered form, using liquid nitrogen. The powdered samples were homogenized in $0.05 \mathrm{M}$ phosphate buffer ( $\mathrm{pH}: 7.8$ ) and filtered using a muslin cloth and then centrifuged at for $10 \mathrm{~min}$; temp. $4^{\circ} \mathrm{C}$ at $12,000 \times \mathrm{g}$ and the filtrate collected was used for the analysis of various enzymes.

To measure activity, the samples were homogenized in a phosphate buffer $(50 \mathrm{mM}$ potassium phosphate buffer; $\mathrm{pH}$ 7.0) mixture containing; $0.1 \mathrm{mM}$ of EDTA and $1 \mathrm{mM}$ dithiothreitol (DTT), as described by Dixit et al. (2011). SOD activity was determined by assessing its ability to inhibit photochemical reduction nitro blue tetrazolium (NBT); POD activity was assayed following the modified protocol of Chance and Maehly (1955), whereas, Catalase (CAT) enzyme assay was done according to Aebi (1984) by monitoring the decrease in the absorbance at $240 \mathrm{~nm}\left(\varepsilon=39.4 \mathrm{mM}^{-1} \mathrm{~cm}^{-1}\right)$.

\section{Statistical analysis}

Data generated were subjected to Analysis of variance (ANOVA) and the mean differences of data were tested using Fisher's LSD test by Minitab-17 statistical software. Differences among values at $\mathrm{P} \leq 0.05$ were considered as significant.

\section{Results}

\section{Growth parameters}

Increasing $\mathrm{Cd}$ and $\mathrm{Pb}$ concentrations reduced plant growth parameters such as plant height, number of leaves / plants; internode distance, and the fresh and dry mass of Dablia variabilis (Table 1). This reduction was more prominent at higher $\mathrm{Cd}(\mathrm{Cd} 3)$ and $\mathrm{Pb}(\mathrm{Pb} 3)$ concentrations. However, due to the application of EDTA as well as SDS, the growth parameters showed significant recovery, which was much more significant under EDTA+SDS [E1] combinations, than when augmented with EDTA and SDS alone concentrations (Table 1). The combined amendment concentrations with $\mathrm{HMs}(\mathrm{Cd} 1+\mathrm{E} 1$ and $\mathrm{Cd} 2+\mathrm{E} 1)$ have recovered plant height by $80.2 \%$ and $79.9 \%$ respectively, concerning the control. A similar trend was observed with $\mathrm{Pb} 1+\mathrm{E} 1$ and $\mathrm{Pb} 2+\mathrm{E} 1$, were the increase in plant height was enhanced by $34.7 \%$ and $57.9 \%$ respectively. However, at higher concentrations of both $\mathrm{Cd} 3+\mathrm{E} 3$ as well as $\mathrm{Pb} 3+\mathrm{E} 3$, the enhancement in growth parameters was insignificant concerning their control $(\mathrm{Cd} 3$ and $\mathrm{Pb} 3)$. This positive correlation with $\mathrm{E} 1$ and $\mathrm{E} 2$ along with their $\mathrm{Cd} 1, \mathrm{~Pb} 1$ and $\mathrm{Cd} 2, \mathrm{~Pb} 2$, were observed in all the growth parameters studied (viz. number of leaves, internode distance and plant fresh and dry weights). Also, EDTA has shown better performance in enhancing all the growth parameters than SDS along the concentration gradient under both $\mathrm{Cd}$ and $\mathrm{Pb}$ stresses (Table 1).

\section{Tolerance index (TI) and translocation factor (Tf)}

With an increase in $\mathrm{Cd}$ and $\mathrm{Pb}$ concentration in the media, their accumulation in root and shoot was significantly decreased, with a higher content in roots. At higher concentrations of both $\mathrm{HMs}(\mathrm{Cd} 3$ and $\mathrm{Pb} 3)$, stress seemed to be saturated and further accumulation and translocation of HMs from root to shoot declined as evident from the data of Table 2 . However, on chemical amendments, a significant increase in both tolerance index ratio (TI) and translocation factor (Tf) was observed (Table 2). Combined chemical amendment (E3) increased the shoot tolerance index (STI) by $15.9-50.8 \%$ and $23.2-60.4 \%$ under the corresponding and $\mathrm{Pb}$ 
concentrations, respectively. Similarly, Tf were corresponding to the concentrations of the chemical amendments (E1, E2 and E3) along with their concentration gradient (Table 2). However, both TI and Tf levels were recorded higher in plants when under E1 amendment in comparison to E2 and E3.

Table 1. Plant growth parameters of Dablia Variabilis including plant height, number of leaves per plant; internode distance, fresh and dry weights of the plant under various $\mathrm{Cd}$ and $\mathrm{Pb}$ concentrations and influenced by the inorganic amendments viz. (EDTA+SDS=E3), EDTA (E2) and SDS (E3)

\begin{tabular}{|c|c|c|c|c|c|}
\hline Treatments & $\begin{array}{l}\text { Plant } \\
\text { height }\end{array}$ & $\begin{array}{c}\text { Leaf } \\
\text { number }\end{array}$ & $\begin{array}{l}\text { Internode } \\
\text { distance }\end{array}$ & $\begin{array}{l}\text { Fresh } \\
\text { weight }\end{array}$ & $\begin{array}{c}\text { Dry } \\
\text { weight }\end{array}$ \\
\hline Control & $19.27 \pm 1.2^{\mathrm{a}}$ & $13.00 \pm 1.1^{\mathrm{a}}$ & $2.36 \pm 0.2^{\mathrm{a}}$ & $1.38 \pm 0.1^{\mathrm{a}}$ & $0.24 \pm 0.01^{\mathrm{a}}$ \\
\hline $\mathrm{Cd} 1+\mathrm{E} 0$ & $12.92 \pm 1.1^{\mathrm{b}, \mathrm{g}}$ & $12.50 \pm 1.2^{\mathrm{b}}$ & $1.76 \pm 0.2^{\mathrm{b}}$ & $0.73 \pm 0.1^{\mathrm{b}}$ & $0.12 \pm 0.02^{\mathrm{b}}$ \\
\hline $\mathrm{Cd} 2+\mathrm{E} 0$ & $11.15 \pm 1.3^{c}$ & $10.00 \pm 1.0^{c}$ & $1.53 \pm 0.1^{\mathrm{b}}$ & $0.65 \pm 0.1^{\mathrm{c}}$ & $0.10 \pm 0.01^{b}$ \\
\hline $\mathrm{Cd} 3+\mathrm{E} 0$ & $10.97 \pm 1.0^{\mathrm{d}}$ & $09.00 \pm 1.2^{\mathrm{d}}$ & $1.30 \pm 0.3^{\mathrm{c}}$ & $0.57 \pm 0.2^{c}$ & $0.09 \pm 0.04^{c}$ \\
\hline $\mathrm{Cd} 1+\mathrm{E} 1$ & $20.90 \pm 1.2^{\mathrm{a}, \mathrm{e}}$ & $13.00 \pm 1.0^{\mathrm{a}}$ & $1.98 \pm 0.1^{\mathrm{a}}$ & $1.01 \pm 0.1^{\mathrm{a}}$ & $0.20 \pm 0.01^{\mathrm{a}}$ \\
\hline $\mathrm{Cd} 2+\mathrm{E} 1$ & $19.25 \pm 1.4^{\mathrm{e}, \mathrm{f}}$ & $13.50 \pm 1.5^{a}$ & $1.90 \pm 0.1^{\mathrm{a}}$ & $0.99 \pm 0.3^{a}$ & $0.17 \pm 0.02^{a}$ \\
\hline $\mathrm{Cd} 3+\mathrm{E} 1$ & $15.95 \pm 1.0^{\mathrm{g}}$ & $10.50 \pm 1.0^{c}$ & $1.89 \pm 0.2^{\mathrm{a}}$ & $0.83 \pm 0.1^{\mathrm{b}}$ & $0.14 \pm 0.02^{b}$ \\
\hline $\mathrm{Cd} 1+\mathrm{E} 2$ & $15.35 \pm 2.1^{\mathrm{g}}$ & $13.25 \pm 1.2^{\mathrm{a}}$ & $1.86 \pm 0.1^{\mathrm{a}}$ & $0.98 \pm 0.4^{a}$ & $0.11 \pm 0.04^{\mathrm{b}}$ \\
\hline $\mathrm{Cd} 2+\mathrm{E} 2$ & $17.02 \pm 1.9^{\mathrm{a}, \mathrm{e}, \mathrm{h}}$ & $10.50 \pm 1.4^{\mathrm{c}}$ & $1.68 \pm 0.3^{\mathrm{b}}$ & $0.77 \pm 0.1^{b}$ & $0.11 \pm 0.01^{b}$ \\
\hline $\mathrm{Cd} 3+\mathrm{E} 2$ & $13.35 \pm 1.0^{\mathrm{g}}$ & $09.75 \pm 1.2^{\mathrm{d}}$ & $1.40 \pm 0.3^{\mathrm{b}}$ & $0.61 \pm 0.1^{\mathrm{c}}$ & $0.09 \pm 0.01^{\mathrm{c}}$ \\
\hline $\mathrm{Cd} 1+\mathrm{E} 3$ & $15.87 \pm 1.3^{\mathrm{g}, \mathrm{i}}$ & $13.50 \pm 1.1^{\mathrm{a}}$ & $1.81 \pm 0.1^{\mathrm{a}}$ & $0.95 \pm 0.5^{a}$ & $0.17 \pm 0.01^{\mathrm{a}}$ \\
\hline $\mathrm{Cd} 2+\mathrm{E} 3$ & $17.15 \pm 1.3^{\mathrm{a}, \mathrm{e}, \mathrm{h}}$ & $11.50 \pm 1.5^{a}$ & $1.49 \pm 0.1^{\mathrm{b}}$ & $0.74 \pm 0.5^{b}$ & $0.11 \pm 0.01^{b}$ \\
\hline $\mathrm{Cd} 3+\mathrm{E} 3$ & $13.85 \pm 1.4^{\mathrm{g}}$ & $11.00 \pm 1.5^{a}$ & $1.38 \pm 0.3^{\mathrm{b}}$ & $0.58 \pm 0.1^{\mathrm{c}}$ & $0.10 \pm 0.01^{\mathrm{b}}$ \\
\hline Control & $21.92 \pm 1.2^{\mathrm{a}}$ & $12.25 \pm 1.5^{\mathrm{a}}$ & $2.53 \pm 0.3^{\mathrm{a}}$ & $1.29 \pm 0.1^{\mathrm{a}}$ & $0.24 \pm 0.01^{\mathrm{a}}$ \\
\hline $\mathrm{Pb} 1+\mathrm{E} 0$ & $17.00 \pm 1.8^{\mathrm{i}}$ & $09.75 \pm 1.4^{\mathrm{d}}$ & $1.63 \pm 0.1^{\mathrm{b}}$ & $0.84 \pm 0.1^{\mathrm{a}}$ & $0.09 \pm 0.02^{b}$ \\
\hline $\mathrm{Pb} 2+\mathrm{E} 0$ & $11.37 \pm 1.3^{\mathrm{c}, j}$ & $08.50 \pm 1.5^{\mathrm{d}}$ & $1.48 \pm 0.1^{\mathrm{c}}$ & $0.56 \pm 0.1^{\mathrm{c}}$ & $0.08 \pm 0.01^{\mathrm{b}}$ \\
\hline $\mathrm{Pb} 3+\mathrm{E} 0$ & $07.95 \pm 1.0^{\mathrm{k}}$ & $06.75 \pm 1.0^{\mathrm{e}}$ & $1.31 \pm 0.3^{\mathrm{d}}$ & $0.48 \pm 0.1^{\mathrm{c}}$ & $0.09 \pm 0.03^{c}$ \\
\hline $\mathrm{Pb} 1+\mathrm{E} 1$ & $22.30 \pm 1.3^{\mathrm{e}, \mathrm{f}}$ & $11.50 \pm 1.5^{\mathrm{a}}$ & $1.96 \pm 0.2^{\mathrm{a}}$ & $0.91 \pm 0.1^{a}$ & $0.20 \pm 0.01^{\mathrm{a}}$ \\
\hline $\mathrm{Pb} 2+\mathrm{E} 1$ & $18.50 \pm 1.2^{\mathrm{I}, \mathrm{h}}$ & $11.00 \pm 1.3^{a}$ & $1.81 \pm 0.1^{\mathrm{a}}$ & $0.74 \pm 0.1^{\mathrm{b}}$ & $0.17 \pm 0.01^{a}$ \\
\hline $\mathrm{Pb} 3+\mathrm{E} 1$ & $15.57 \pm 1.5^{\mathrm{g}}$ & $07.25 \pm 1.4^{\mathrm{d}}$ & $1.68 \pm 0.2^{\mathrm{b}}$ & $0.64 \pm 0.1^{\mathrm{c}}$ & $0.15 \pm 0.01^{a}$ \\
\hline $\mathrm{Pb} 1+\mathrm{E} 2$ & $17.50 \pm 1.4^{\mathrm{i}, \mathrm{h}}$ & $10.50 \pm 1.4^{\mathrm{a}}$ & $1.80 \pm 0.4^{\mathrm{a}}$ & $0.89 \pm 0.1^{\mathrm{a}}$ & $0.14 \pm 0.01^{\mathrm{a}}$ \\
\hline $\mathrm{Pb} 2+\mathrm{E} 2$ & $17.72 \pm 1.1^{\mathrm{i}, \mathrm{h}}$ & $09.75 \pm 1.3^{\mathrm{b}}$ & $1.78 \pm 0.2^{\mathrm{b}}$ & $0.69 \pm 0.2^{b}$ & $0.09 \pm 0.01^{\mathrm{b}}$ \\
\hline $\mathrm{Pb} 3+\mathrm{E} 2$ & $10.80 \pm 1.4^{\mathrm{d}}$ & $07.25 \pm 1.2^{\mathrm{d}}$ & $1.44 \pm 0.4^{\mathrm{c}}$ & $0.52 \pm 0.1^{\mathrm{c}}$ & $0.08 \pm 0.01^{\mathrm{b}}$ \\
\hline $\mathrm{Pb} 1+\mathrm{E} 3$ & $16.72 \pm 1.6^{\mathrm{g}, \mathrm{i}}$ & $11.50 \pm 1.4^{a}$ & $1.86 \pm 0.1^{\mathrm{a}}$ & $0.86 \pm 0.2^{a}$ & $0.08 \pm 0.01^{\mathrm{b}}$ \\
\hline $\mathrm{Pb} 2+\mathrm{E} 3$ & $11.75 \pm 1.2^{\mathrm{g}}$ & $08.75 \pm 1.3^{\mathrm{b}}$ & $1.53 \pm 0.1^{\mathrm{c}}$ & $0.69 \pm 0.1^{\mathrm{c}}$ & $0.07 \pm 0.01^{\mathrm{a}}$ \\
\hline $\mathrm{Pb} 3+\mathrm{E} 3$ & $10.65 \pm 1.5^{\mathrm{g}}$ & $07.25 \pm 1.7^{\mathrm{e}}$ & $1.32 \pm 0.1^{\mathrm{c}}$ & $0.49 \pm 0.1^{c}$ & $0.06 \pm 0.01^{b}$ \\
\hline
\end{tabular}

Dissimilar letters within mean and between columns are significantly different at $p \leq 0.05$ level of significance by applying Fisher's LSD Test. Cadmium $(\mathrm{Cd})$ concentrations of $(0=$ Control, $\mathrm{Cd} 1=10, \mathrm{Cd} 2=25$, and $\mathrm{Cd} 3=100 \mathrm{mg} \mathrm{kg}$ 1 and Lead $(\mathrm{Pb})$ concentrations of $\left(0=\right.$ Control, $\mathrm{Pb} 1=500, \mathrm{~Pb} 2=1000$, and $\left.\mathrm{Pb} 3=5000 \mathrm{mg} \mathrm{kg}^{-1}\right)$ were applied in the pot with the chemical amendments, $2.5 \mathrm{mM}$ EDTA + $2 \mathrm{mM}$ SDS [E1], $2.5 \mathrm{mM}$ EDTA [E2] and $2 \mathrm{mM}$ SDS [E3]. $[\mathrm{E} 0]=$ Without any amendment

\section{Relative water content}

The effect of $\mathrm{Cd}$ and $\mathrm{Pb}$ stresses over relative water content (RCW) under the influence of inorganic chemical amendments is shown in Figure 1. With the increase in Cd stress, D. variabilis seedlings showed 10\%$20.5 \%$ reduction in RWC with respect to the control. Similarly, under Pb Stress the RWC was observed to be declined from 10\%-23\% in the plants with respect to the control (Figure 1). However, the inorganic amendments increased RCW by $70.5-96.1 \%$ with E1 under Cd stress and by $80.4 \%-100 \%$ with $\mathrm{E} 1$ under $\mathrm{Pb}$ stress. A similar trend was shown when augmented with E2 and E2 concentrations alone. Nevertheless, recovery was much significant under E1 than E2 and E3. 
Table 2. Effect of increasing concentration of $\mathrm{Cd}$ and $\mathrm{Pb}$ in the growth medium and the influence of inorganic amendments viz. EDTA+SDS in combination [E1], EDTA [E2] and SDS [E3] alone, on the root tolerance index (root TI\%), shoot tolerance index (shoot TI\%) and translocation factor values (TFvalues)

\begin{tabular}{|c|c|c|c|}
\hline Treatments & $\begin{array}{l}\text { Root tolerance index } \\
(\operatorname{root} \text { TI \%) }\end{array}$ & $\begin{array}{c}\text { Shoot tolerance index } \\
(\text { Shoot TI \%) }\end{array}$ & TF value \\
\hline $\mathrm{Cd} 1+\mathrm{E} 0$ & 40.4 & 62.41 & 0.552 \\
\hline $\mathrm{Cd} 2+\mathrm{E} 0$ & 34.26 & 40.61 & 0.513 \\
\hline $\mathrm{Cd} 3+\mathrm{E} 0$ & 29.91 & 20.11 & 0.390 \\
\hline $\mathrm{Cd} 1+\mathrm{E} 1$ & 85.21 & 90.21 & 0.791 \\
\hline $\mathrm{Cd} 2+\mathrm{E} 1$ & 80.32 & 85.91 & 0.781 \\
\hline $\mathrm{Cd} 3+\mathrm{E} 1$ & 90.13 & 82.61 & 0.803 \\
\hline $\mathrm{Cd} 1+\mathrm{E} 2$ & 56.21 & 79.94 & 0.725 \\
\hline $\mathrm{Cd} 2+\mathrm{E} 2$ & 60.10 & 77.26 & 0.723 \\
\hline $\mathrm{Cd} 3+\mathrm{E} 2$ & 64.50 & 70.46 & 0.672 \\
\hline $\mathrm{Cd} 1+\mathrm{E} 3$ & 51.10 & 80.26 & 0.710 \\
\hline $\mathrm{Cd} 2+\mathrm{E} 3$ & 54.60 & 77.10 & 0.683 \\
\hline $\mathrm{Cd} 3+\mathrm{E} 3$ & 60.01 & 77.01 & 0.603 \\
\hline $\mathrm{Pb} 1+\mathrm{E} 0$ & 50.50 & 61.64 & 0.503 \\
\hline $\mathrm{Pb} 2+\mathrm{E} 0$ & 39.16 & 30.26 & 0.452 \\
\hline $\mathrm{Pb} 3+\mathrm{E} 0$ & 33.69 & 78.15 & 0.313 \\
\hline $\mathrm{Pb} 1+\mathrm{E} 1$ & 81.22 & 106.21 & 0.690 \\
\hline $\mathrm{Pb} 2+\mathrm{E} 1$ & 75.30 & 102.96 & 0.791 \\
\hline $\mathrm{Pb} 3+\mathrm{E} 1$ & 74.31 & 100.76 & 0.881 \\
\hline $\mathrm{Pb} 1+\mathrm{E} 2$ & 74.51 & 97.64 & 0.603 \\
\hline $\mathrm{Pb} 2+\mathrm{E} 2$ & 80.16 & 89.26 & 0.752 \\
\hline $\mathrm{Pb} 3+\mathrm{E} 2$ & 81.51 & 87.64 & 0.713 \\
\hline $\mathrm{Pb} 1+\mathrm{E} 3$ & 61.16 & 90.26 & 0.527 \\
\hline $\mathrm{Pb} 2+\mathrm{E} 3$ & 78.69 & 90.15 & 0.688 \\
\hline $\mathrm{Pb} 3+\mathrm{E} 3$ & 80.01 & 89.01 & 0.703 \\
\hline
\end{tabular}

Dissimilar letters within mean and between columns are significantly different at $p \leq 0.05$ level of significance by applying Fisher's LSD Test. Data represent the mean \pm SE of three different experiments $(n=10)$.Cadmium $(\mathrm{Cd})$ concentrations of $\left(0=\right.$ Control, $\mathrm{Cd} 1=10, \mathrm{Cd} 2=25$, and $\mathrm{Cd} 3=100 \mathrm{mg} \mathrm{kg}^{-1}$ and Lead $(\mathrm{Pb})$ concentrations of $(0=$ Control, $\mathrm{Pb} 1=500, \mathrm{~Pb} 2=1000$, and $\mathrm{Pb} 3=5000 \mathrm{mg} \mathrm{kg}-1)$ were applied in the pot with the chemical amendments, 2.5 $\mathrm{mM}$ EDTA + $2 \mathrm{mM}$ SDS [E1], $2.5 \mathrm{mM}$ EDTA [E2] and $2 \mathrm{mM}$ SDS [E3]. [E0] = Without any amendment.

\section{Chlorophyll, total soluble protein and proline contents}

A significant decline in chlorophyll a (Chl-a), chlorophyll b (Chl-b) and carotenoid concentrations were found in the leaf samples of $D$. variabilis with a concomitant increase in $\mathrm{Cd}$ and $\mathrm{Pb}$ concentration in soil culture with respect to control (Figure 2 A,B,C). However, enrichment within organic amendments at E1, E2 and E3 significantly enhances the pigment content under $\mathrm{Cd}$ and Pbtreated conditions. Higher chlorophyll and carotenoid concentrations were observed in leaves under $\mathrm{Cd}$ and $\mathrm{Pb}$ stress when augmented with E1treatment along their concentration gradient.

The soluble protein and proline contents in leaves increased in a dose-dependent manner with an increase in the $\mathrm{Cd}$ and $\mathrm{Pb}$ concentration of the soil culture (Figure 3A, B). Application of inorganic amendments (E1, E2 and E3) also enhanced the total soluble protein content significantly in leaves compared to the respective $\mathrm{Cd}$ and $\mathrm{Pb}$ treated samples. The proline content also showed significant increase under $\mathrm{Cd}$ and $\mathrm{Pb}$ stresses (Figure 3B). However, it declined markedly by the addition of $\mathrm{E} 1$. 


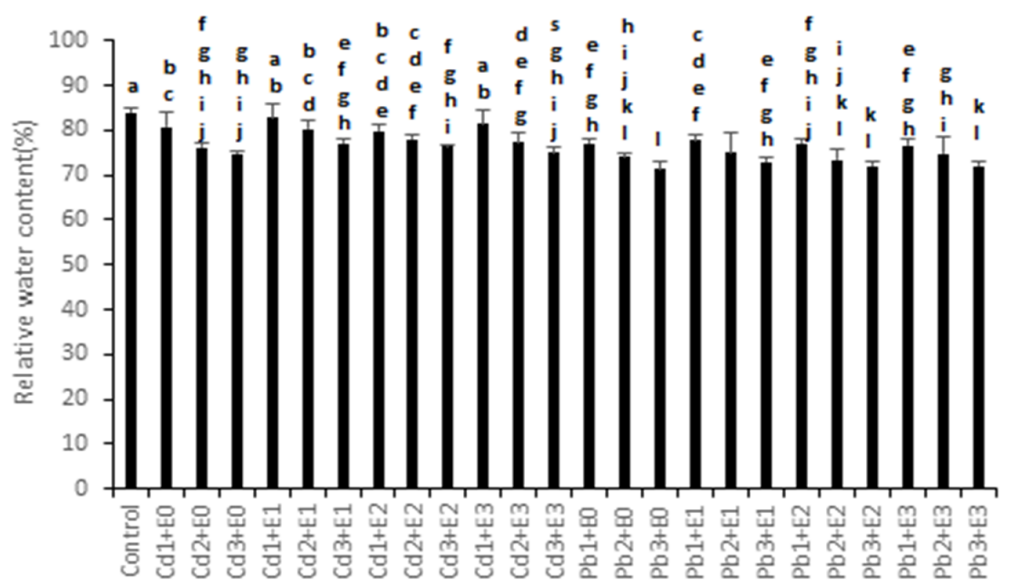

Figure 1. Effect of EDTA and SDS on relative water content (RWC) in leaves of Dablia variabilis seedlings under $\mathrm{Cd}$ and $\mathrm{Pb}$ stress. Dissimilar letters within mean and between columns are significantly different at $\mathrm{p} \leq 0.05$ level of significance by applying Fisher's LSD test
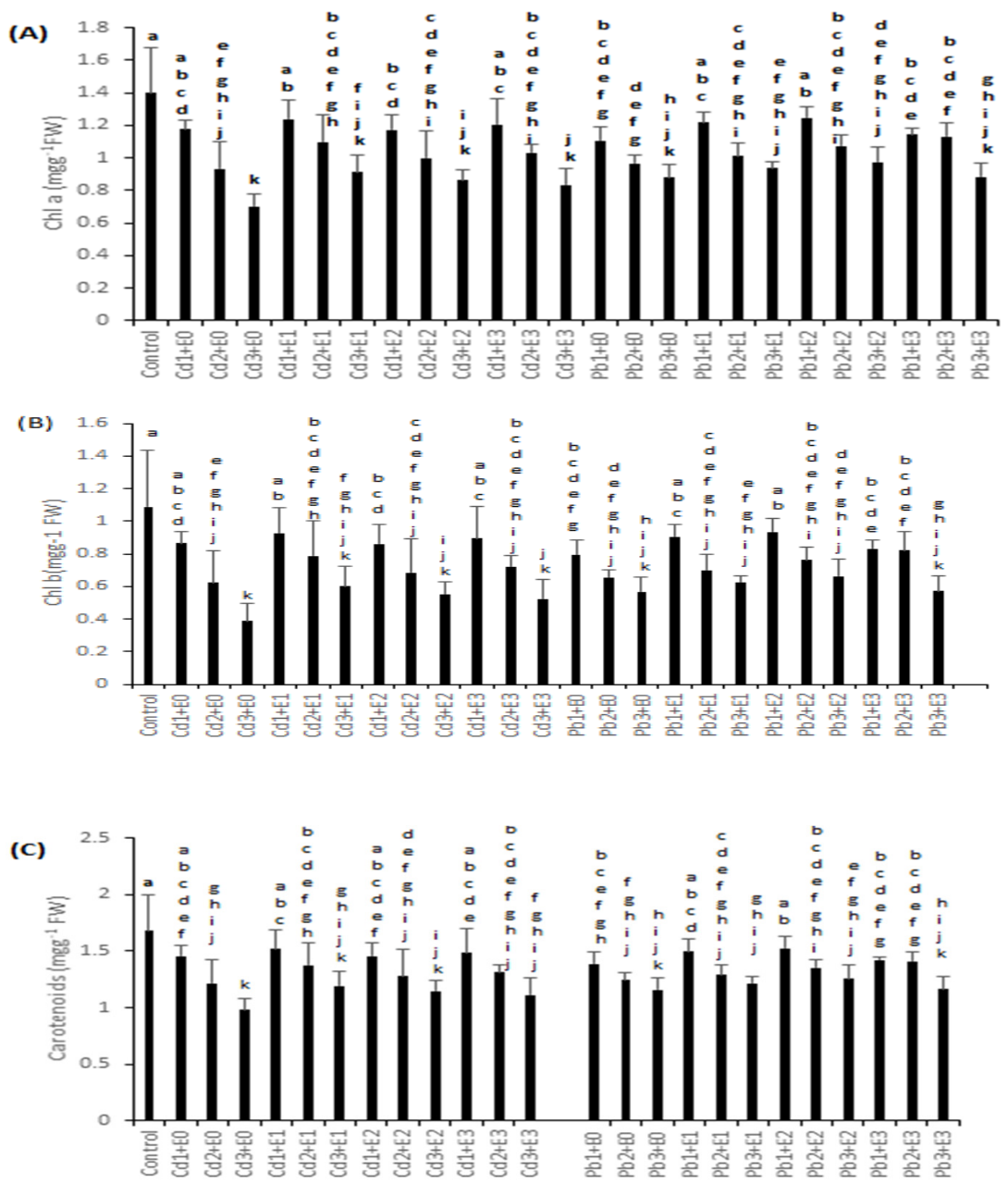

Figure 2. Effect of EDTA and SDS on Chl a (A), Chl b(B), carotenoids (C) content in leaves of Dablia variabilis seedlings under $\mathrm{Cd}$ and $\mathrm{Pb}$ stress. Dissimilar letters within mean and between columns are significantly different at $\mathrm{p} \leq 0.05$ level of significance by applying Fisher's LSD test 

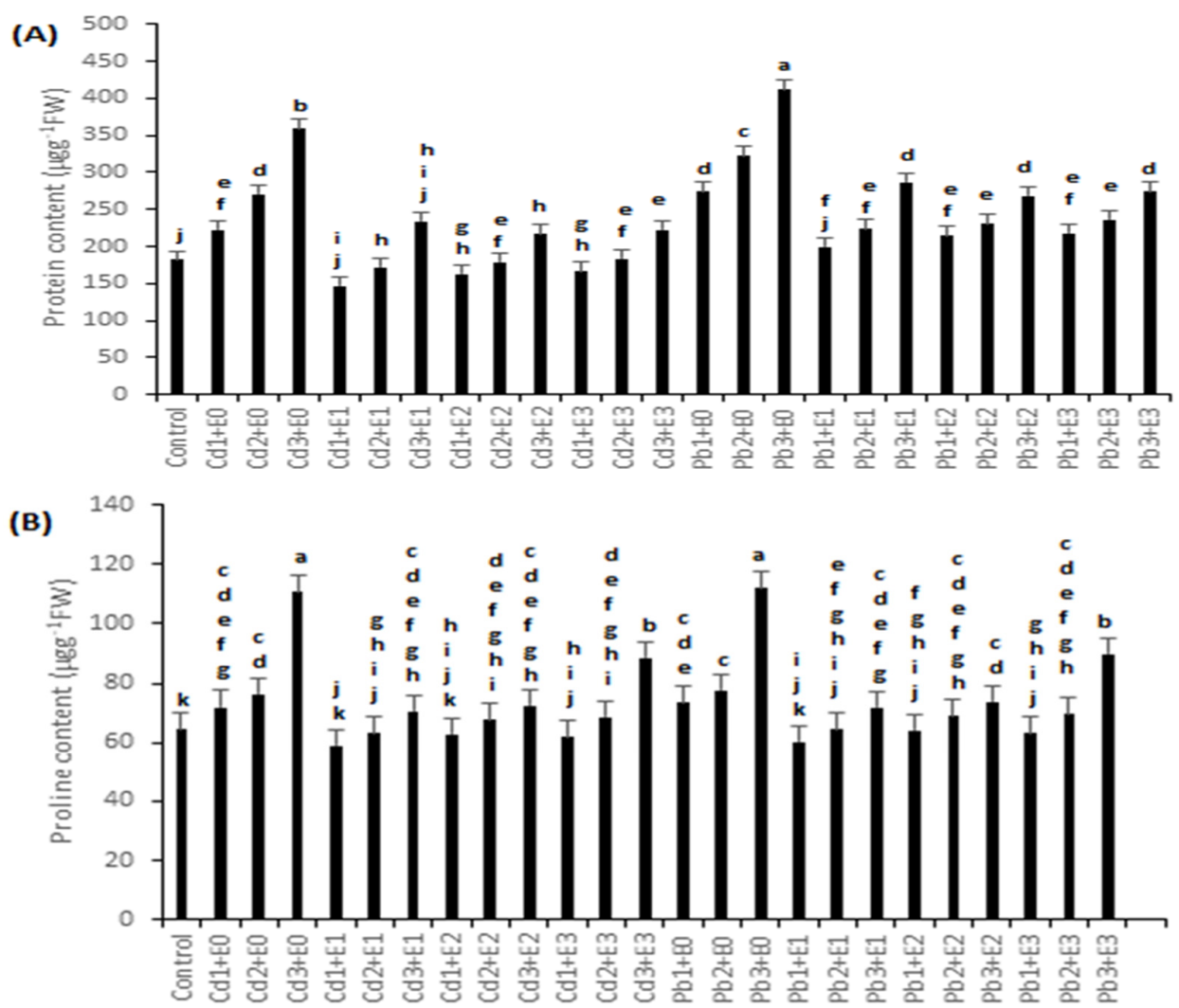

Figure 3. Effect of EDTA and SDS on soluble protein (A), proline (B) content in leaves of Dablia variabilis seedlings under $\mathrm{Cd}$ and $\mathrm{Pb}$ stress. Dissimilar letters within mean and between columns are significantly different at $\mathrm{p} \leq 0.05$ level of significance by applying Fisher's LSD test

\section{$M D A$ and $\mathrm{H}_{2} \mathrm{O}_{2}$ content}

The $\mathrm{H}_{2} \mathrm{O}_{2}$ and MDA levels were significantly increased, with respect to control, in leaves of $D$. variabilis when subjected to different $\mathrm{Cd}$ and $\mathrm{Pb}$ concentrations (Figure 4). Nevertheless, extraneous applications of EDTA (E2) and SDS (E3) reduced the $\mathrm{H}_{2} \mathrm{O}_{2}$ as well as MDA contents. However, application of E1 under Cd and $\mathrm{Pb}$ stresses caused a significant decline in $\mathrm{H}_{2} \mathrm{O}_{2}$ and MDA compared to $\mathrm{E} 2$ and $\mathrm{E} 3$ treatments treatment reduced the $\mathrm{H}_{2} \mathrm{O}_{2}$ and MDA by 20.2-36.7\% under $\mathrm{Cd}$ stress and by $35.7-62.1 \%$ under $\mathrm{Pb}$ stress along the concentration gradient. 

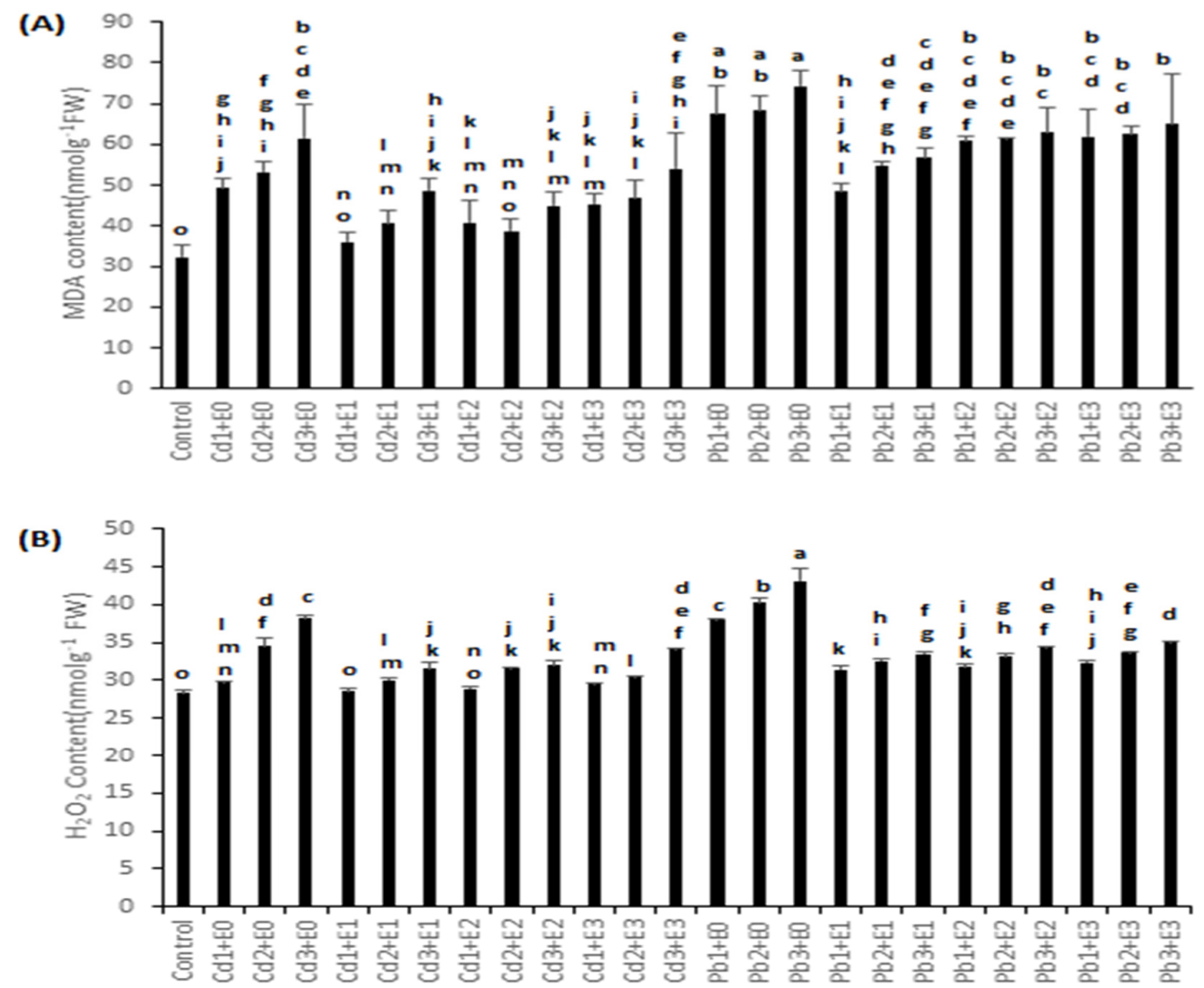

Figure 4. Effect of EDTA and SDS on MDA (A), $\mathrm{H}_{2} \mathrm{O}_{2}$ (B) content in leaves of Dablia variabilis seedlings under $\mathrm{Cd}$ and $\mathrm{Pb}$ stress. Dissimilar letters within mean and between columns are significantly different at $\mathrm{p} \leq 0.05$ level of significance by applying Fisher's LSD test

\section{Antioxidant defense mechanism (SOD, POD, CAT and APX)}

The activity of antioxidant enzymesviz., superoxide dismutase, guaiacol peroxidase, catalase and ascorbate peroxidase (SOD, POD, CAT and APX) in the leaves of D. variabilis exposed to $\mathrm{Cd}$ and $\mathrm{Pb}$ treatments either alone or in combination with chemical enhancers (EDTA+SDS) is depicted in Figure 5. The enzyme activities showed a concomitant decrease with each increment level of $\mathrm{Cd}$ and $\mathrm{Pb}$ treatment, as compared to control. However, under EDTA and SDS augmentation, SOD, POD, CAT, and APX activity was significantly enhanced at all levels of $\mathrm{Cd}$ and $\mathrm{Pb}$ treatments with respect to control. Nevertheless, the combined concentrations of $\mathrm{E} 1$ generated signifycantly greater activity of these antioxidant defense enzymes.

Further, a negative correlation was observed between $\mathrm{H}_{2} \mathrm{O}_{2}$ and MDA content and enzyme activities, which may indicate the role of enzyme activities in lowering the oxidative damage in $D$. variabilis under $\mathrm{Cd}$ and $\mathrm{Pb}$ toxicity. 

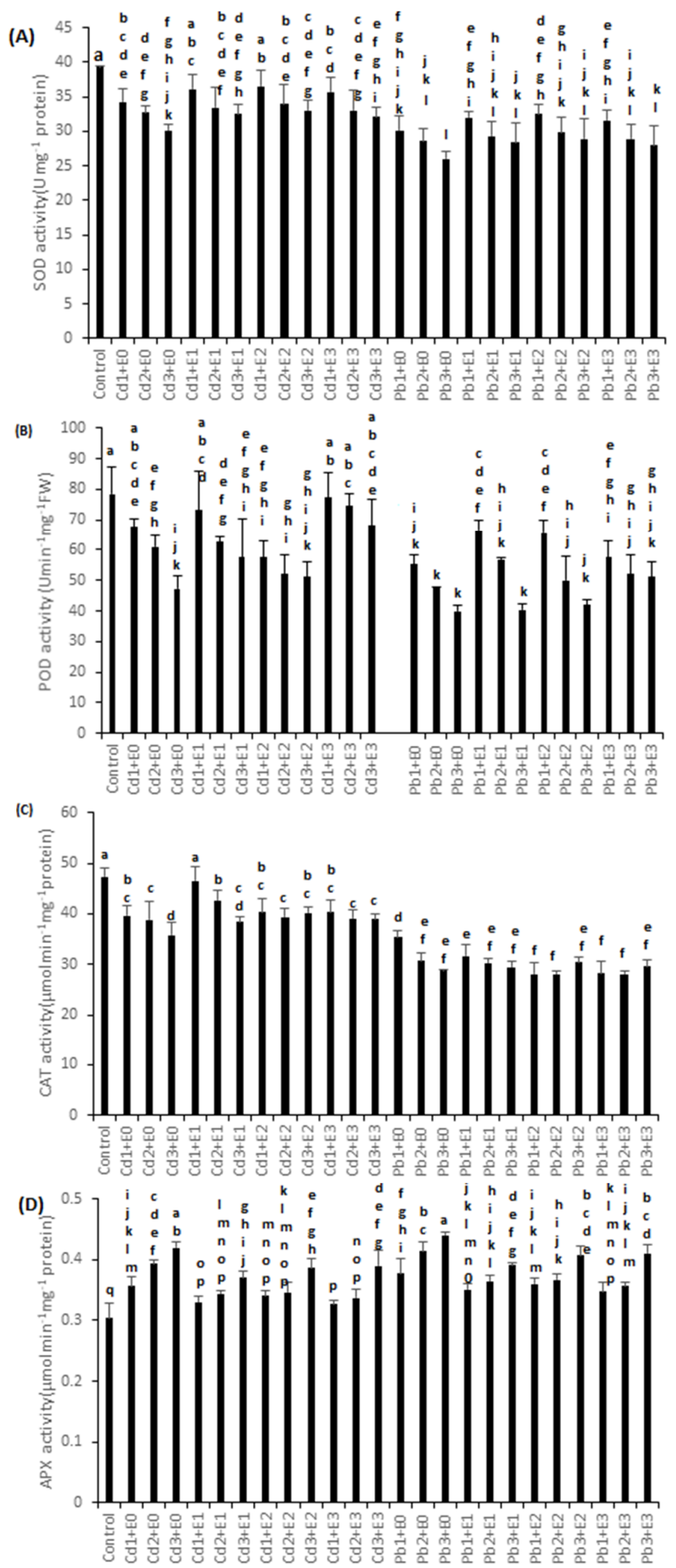

Figure 5. Effect of EDTA and SDS on SOD (A), POD (B), CAT (C), and APX (D) activity in leaves of Dahlia variabilis seedlings under $\mathrm{Cd}$ and $\mathrm{Pb}$ stress. Dissimilar letters within mean and between columns are significantly different at $\mathrm{p} \leq 0.05$ level of significance by applying Fisher's LSD test 


\section{Discussion}

Plant growth, metal accumulation and translocation factor (TF)

$\mathrm{Cd}$ and $\mathrm{Pb}$ are generally present in the soil in high concentration due to agricultural malpractices (Chen et al., 2009). These metals are readily available to plants and cause serious biochemical as well as physiological disturbances in their cellular mechanism (Hameed et al., 2017). In the present study, the significant decline recorded in growth parameters of $\mathrm{Cd}$ and $\mathrm{Pb}$ treated Dablia variabilis seedlings was possibly due to the disturbed homeostasis, inhibited mitotic index and restrained aquaporins as well as high accumulation of these metals in various plant organs (Gajewska and Skłodowska, 2010; Hakeem et al., 2019). Inorganic chemical amendments (EDTA and SDS) have significantly improved the growth parameters, tolerance index (TI) and translocation factor (TF) and the overall growth of plants was higher in plants treated with chelating agents, compared to the control (Table 1). EDTA, as well as SDS-assisted escalation in growth and biomass, has been reported in sudangrass, sweet sorghum and Calendula officinalis (Mani et al., 2014; Székely et al., 2011; Liu et al., 2010). Liu et al. (2010) described that the use of SDS and EGTA could not only enhance the growth of Calendula officinalis but also increased its Cd-accumulation capacity. In the current study, combined concentrations of EDTA + SDS were more effective in enhancing the growth and recovery processes. Our study confirms the positive correlation of tolerance index as well as translocation factor with both EDTA alone as well as in combination with SDS. This counters to the observations of Liu et al. (2010) about poor growth of Calendula officinalis under EDTA, particularly at higher $(100 \mathrm{mg} / \mathrm{kg})$ levels in Cd-spiked soils. This might be due to species-specific effect because it is known that EDTA increases both mobility of soil $\mathrm{Pb}$ as well as $\mathrm{Pb}$ concentrations in plants (Wang et al., 2016; Hasan et al., 2019). Our study has also shown that EDTA application enhances $\mathrm{Cd}$ and $\mathrm{Pb}$ shoot to root ratio, as compared to $\mathrm{Cd}$ and $\mathrm{Pb}$-treatments (Table 1). This is in line with the study of Székely et al. (2011), who reported that EDTA chelating effect in sweet sorghum and Sudan grass plants under Cu stress (Székely et al., 2011).

The uptake and translocation of heavy metals in plants differ with plant species and genotype (Gill and Tuteja, 2010; Ansari et al., 2012; Sabir et al., 2015b). In the present study, accumulation of Cd and Pb in root and shoot of $D$. variabilis increases with increasing treatment. TF characterizes the plant's ability to translocate metals from root to shoot (Placek et al., 2016). Cd and Pb concentration in shoots of $D$. variabilis were lower as compared to roots. Therefore, TF was observed be $<1$, (Table 2), indicating that large amounts of Cd and Pbwererestricted in roots and insignificant amount is translocated to the above-ground parts for that $D$. variabilis could be interestingly considered for phyto-stabilization (Nouri et al., 2011). Our study revealed that D. variabilis accumulates more $\mathrm{Cd}$ and $\mathrm{Pb}$ under combined EDTA + SDS treatment due to the secretion and chelation of $\mathrm{Cd}$ and $\mathrm{Pb}$ using organic acids, viz. oxalic acid or citric acid (Ma et al., 1997). In the absence of these inorganic amendments, retention of $\mathrm{Cd}$ and $\mathrm{Pb}$ in the root cells might be due to insolubilization at the root surface or compartmentation in cells, avoiding the release of these metals to the xylem. It is also reported that the organic acids, phytochelatins and other ligands secreted by root cells lead to the formation of complex compounds that are important for the retention of toxic metals in roots (Ma et al., 1997).In some studies, it was shown that EDTA form complexes in solution, then enter plants (Hasan et al., 2019). Recently Souza et al. (2009) reported that the heavy metal behaviour of a non-hyperaccumulator plant is relatively slow, but the metal uptake increases quickly after the application of chemical amendments (EDTA) along with metals

In the current investigation, both EDTA and SDS, particularly when used in combination, increased $\mathrm{Cd}$ and $\mathrm{Pb}$ contents in both roots and shoots of $D$. variabilis, as their dosage was raised in soil culture media (Table 2). Similar results were recorded by Marschner (1995) under Cu levels in leaves that were above the threshold for $\mathrm{Cu}$ toxicity in plants. The reason is that EDTA and SDS act as chelating agents to reduce the toxic effects of $\mathrm{Cu}$ and improve metal availability (Evangelou and Marsi, 2001; Zhang et al., 2008). The enhancement in $\mathrm{Cd}$ and $\mathrm{Pb}$ uptake with EDTA application might be because roots can liberate trace metals 
from dissociated organometallic compounds, as recorded by Nor and Cheng (1986), and this enhances metal uptake by plants (Han et al., 2005; Hasan et al., 2019).

The total $\mathrm{Cd}$ and $\mathrm{Pb}$ contents were found to be more in shoot than in roots of D. variabilis under all levels of EDTA + SDS concentration. Therefore, this phenomenon could be used to rejuvenate the health of soil contaminated with $\mathrm{Cd}$ and $\mathrm{Pb}$. Similar observations were reported by Liu et al. (2010) in Calendula officinalis under the influence of SDS + EGTA combination.

\section{Relative water content, pigment content and other biochemical parameters}

Relative water content (RWC) in D. variabilis was found to decrease under $\mathrm{Cd}$ and $\mathrm{Pb}$ treatments (Figure 1), which corroborates our previous findings (Qureshi et al., 2005; Hakeem et al., 2019) in $\mathrm{Pb}$ and Cdstressed plants. This might be because HM stress stimulates the closure of stomata (Brunet et al., 2008). However, under EDTA and SDS combined treatments, the RWC of Cd and Pb-stressed plants showed a significant enhancement with respect to the control.

Photosynthetic pigments represent as biomarkers of metal stress and thus, play a pivotal role in studying plant-metal dynamic interaction (Khudsar et al., 2001). Plant chlorophyll and carotenoid contents were progressively decreased under $\mathrm{Cd}$ and $\mathrm{Pb}$ stress (Figure 2)possibly due to the substitution of metal ions and inhibition of mineral nutrients viz., $\mathrm{Mn}, \mathrm{K}, \mathrm{Mg}$, which retard the rate of photosynthesis by interfering with photosystems especially with PS-II (Kupper et al., 1998; Bashir et al., 2015). It also interferes with pigment synthesis by interacting with the enzyme namely $\delta$-aminolevulenic acid dehydratase (Prasad and Prasad, 1987). Besides, the decline in pigment may also be associated with peroxidation of chloroplast membranes due to enhanced ROS production. This aligns with an increased level of $\mathrm{H}_{2} \mathrm{O}_{2}$ and MDA production in D. variabilis plants subjected to $\mathrm{Pb}$ stress. The level of carotenoids does not exhibit a significant increase with each increment in $\mathrm{Pb}$ treatment (Figure 3B). Carotenoids play an essential role in to protect $\mathrm{Chl}$ from $\mathrm{ROS}$ by quenching the triplet Chl. Carotenoids are produced as adjunct pigments in plants subjected to metal stresses and play a vital role to maintain the equilibrium state (Hakeem et al., 2019). Our results corroborate those of Habiba et al. (2015) that EDTA enrichment reduced the oxidative damage as indicated by the declining trend of $\mathrm{H}_{2} \mathrm{O}_{2}$ and MDA contents (Figure 4).

Protein is another important biomarker in stress biology (Plata et al., 2009). In the present investigation, the total soluble protein in D. variabilis increased with increase in $\mathrm{Cd}$ and $\mathrm{Pb}$ concentration (Figure 2). This could be due to stimulation of stress proteins under heavy metal exposure or due to the increased activity of metal sequestration pathways to detoxify toxic metals (Bagheri et al., 2015; Hakeem et al., 2019). The concentration of soluble protein content was progressively increasing under the influence of EDTA and SDS. The total soluble sugar content may be closely associated with tolerance to heavy metal stress (Zhang et al., 2015). Herein, found that soluble sugar content of $D$. variabilis showed a concomitant increase with each increment of $\mathrm{Pb}$ stress possibly due to degradation of starch (Figure 5C). It is believed that under $\mathrm{Cd}$ and $\mathrm{Pb}$ stress, accumulation of sugars along with other compatible solutes contribute to osmotic balance (Bohnert et al., 1995). Besides, soluble sugars play an important role in various metabolomic pathways as a signaling molecule and are also involved in structural components of cells (Rosa et al., 2009).

Proline acts as a source of nitrogen besides being used as a signaling molecule, and also acts as an osmoprotectant under stressful conditions (Hayat et al., 2012). In the present study, we found that the proline content of D.variabilis exhibited a dose-dependent increase with increasing $\mathrm{Cd}$ and $\mathrm{Pb}$ stress (Figure 2). This increase is indicative of a correlation between ROS generation and ROS scavenging by proline. Similar results have been reported in tea leaves and roots treated with Al-stress (Hajiboland et al., 2013). However, under the influence of chemical amendments, proline content declined significantly, indicating the release of stabilization of the plant under stressful condition by the influence of these chelating inorganic agents, as noted earlier by Wirosoedarmo et al. (2018). 


\section{Antioxidant enzymes}

Generation of ROS due to heavy metal stress disrupts the various physiological pathways in plants and thus, weakens the defense system by suppressing the activities of osmolytes and antioxidant enzymes (Liu et al. 2010; Ahmad et al., 2012). Stimulation of antioxidant enzymes (SOD, POD, CAT and APX) is the foremost step to reduce the oxidative stress in plants growing at polluted sites. SOD causes reduction of $\mathrm{O}_{2}$ into $\mathrm{H}_{2} \mathrm{O}_{2}$ and $\mathrm{O}_{2}$ and thus maintains $\mathrm{O}_{2}$ radicle in an equilibrium state (Ashraf et al., 2010 a, b; Ashraf et al., 2015; Chen et al., 2015). In our study, SOD level increased significantly in a dose-dependent manner when plants were subjected to $\mathrm{Cd}$ and $\mathrm{Pb}$ stress (Figure 5) and this could be due to over-production ROS or over-expression of SOD-encoding genes (Feng-Tao et al., 2013; Shu et al., 2015). However, in higher concentrations of both Cd and $\mathrm{Pb}$, there was a significant decline in SOD activity, possibly due to enzyme inactivation because of feedback inhibition process. A similar situation was found due to $\mathrm{Cd}$, $\mathrm{Co}$ and $\mathrm{Pb}$ stress in Aeluropus littoralis (Rastgoo and Alemzadeh, 2011). However, under the influence of inorganic amendments, the SOD concentration is enhanced, which causes suppression of oxy free radicles. Similarly, $\mathrm{H}_{2} \mathrm{O}_{2}$ generated as a byproduct of SOD is toxic at higher levels, and needs are removed by conversion to $\mathrm{H}_{2} \mathrm{O}$ through biocatalytic, including CAT, APX and POD. Data on enzyme activities in response to the augmentation of chemical amendments (EDTA and SDS) are depicted in Figure 5. Similar observations were made in Jatropha curcas L. (Shu et al., 2015). The decline observed in CAT activity might be due to enzyme inactivation by excess ROS production or inhibition of enzyme synthesis (Sahu et al., 2012). APX also catalyzes $\mathrm{H}_{2} \mathrm{O}_{2}$ to $\mathrm{H}_{2} \mathrm{O}$ by employing ascorbic acid as a reducing agent and has a higher affinity for $\mathrm{H}_{2} \mathrm{O}_{2}$ than CAT. The present results revealed that APX is increasing in the plants, depending on the concentration ofCd and $\mathrm{Pb}$ and exposure time (Figure 5). The increased APX activity could be correlated to an adaptive mechanism to an enhanced level of ROS content generated during $\mathrm{Pb}$ treatment. POD also caused a reduction of $\mathrm{H}_{2} \mathrm{O}_{2}$ ( $\mathrm{Hu}$ et al., 2012); previous studies have shown a decline, rise or no change in POD activity with respect to heavy metal stress (Schützendübel and Polle, 2002; Dong et al., 2006; Wang et al., 2016). In the present investigation, POD activity increased significantly at E1 (Figure 5) substantiating the findings of Malar et al. (2015) with Eichbornia crassipes and of Wang et al. (2016) with Dimocarpus longan grown under Pb stress. It has been observed that POD activity in metaltolerant plants is adequately high to assist plants in protecting themselves against oxidative damage. Our results suggest that EDTA application sequesters oxidative stress in D. variabilis plants by increasing the activity of antioxidant enzymes. In this study, enhanced plant growth and photosynthetic parameters of $D$. variabilis might have a correlation with elevated activities of antioxidant enzymes due to application of EDTA under Cd stress (Figure 5) which decreased the production of $\mathrm{H}_{2} \mathrm{O}_{2}$ and MDA contents (Figure 5).

Metal phytoremediation enhanced by EDTA and SDS can be affected depending on various biogeochemical processes found in plants, metal, and the soil. Chemical amendment capacity is an important aspect, in order to reduce the time and cost needed for heavy metal contaminated soil. This can be done by increasing the heavy metal bioaccumulation index in plants (Hasan et al., 2019).

\section{Conclusions}

Dablia variabilis appears to be an ideal candidate for chelator-assisted phytoextraction. Extraneous application of EDTA and SDS can significantly improve plant growth, biomass and photosynthetic parameters by increasing the antioxidant enzymes activity and better accumulation of metals. The species studied have a better tolerance to $\mathrm{Cd}$ and $\mathrm{Pb}$ stress. The EDTA and SDS-assisted phytoextraction with $D$. variabilis could be a sustainable and promising approach to rejuvenate soil health contaminated with these metals. 


\section{Acknowledgements}

This project was funded by the Deanship of Scientific Research (DSR) at King Abdulaziz University, Jeddah, under grant no. G-226-130-38. The authors, therefore acknowledge with thanks DSR for technical and financial support.

\section{Conflict of Interests}

The authors declare that there are no conflicts of interest related to this article.

\section{References}

Aebi H (1984). Catalase in vitro. Methods in Enzymology 105:121-126.

Ahmad P, Ozturk M, Gucel S (2012). Oxidative damage and antioxidants induced by heavy metal stress in two cultivars of mustard (Brassica juncea L.) plants. Fresenius Environmental Bulletin 21(10):2953-2961.

Ashraf M, Ozturk M, Ahmad MSA (2010a). Plant adaptation and phytoremediation. Springer, New York, pp 481.

Ashraf M, Ozturk M, Ahmad MSA (2010b). Toxins and their phytoremediation. In: Ashraf M, Ozturk M, Ahmad MSA (Eds.). Plant adaptation and phytoremediation. Springer, Dordrecht, pp 1-34.

Ashraf MY, Roohi M, Iqbal Z, Ashraf M, Ozturk M, Gucel S (2015). Cadmium (Cd) and lead (Pb) induced inhibition in growth and alteration in some biochemical attributes and mineral accumulation in mung bean [Vigna radiata (L.) Wilczek]. Communications in Soil Science and Plant Analysis 47(4):405-413.

Anjum NA, Adam V, Kizek R, Duarte AC, Pereira E, Iqbal M, ... Ahmad I (2015). Nanoscale copper in the soil-plant system: Toxicity and underlying potential mechanisms. Environmental Research 138:306-325.

Anjum NA, Umar S, Iqbal M (2014). Assessment of cadmium accumulation, toxicity and tolerance in Brassicaceae and Fabaceae plants - implications for phytoremediation. Environmental Science and Pollution Research 21(17):10286-10293.

Ansari MKA, Anjum NA, Ahmad A, Umar S, Iqbal M (2012). Heavy metals in soil and plants: An overview of arsenic, cadmium, chromium and mercury. In: Anjum NA, Umar S, Ahmad A (Eds.) Oxidative stress in plants: causes, consequences and tolerance. I.K. International Publishing House, New Delhi, India, pp 499-518.

Aziz MA, Ahmad HR, Corwin DL, Sabir M, Ozturk M, Hakeem KR (2016). Influence of farmyard manure on retention and availability of nickel, zinc and lead in metal-contaminated calcareous loam soils. Journal of Environmental Engineering and Landscape Management 25(3):289-296.

Bagheri R, Bashir H, Ahmad J, Iqbal M, Qureshi MI (2015). Spinach (Spinacia oleracea L.) modulates its proteome differentially in response to salinity, cadmium and their combination stress. Plant Physiology and Biochemistry 97: 235-245.

Bareen FE (2012). Chelate assisted phytoextraction using oil seed brassicas. Environmental Pollution 21:289-311.

Bashir H, Qureshi MI, Ibrahim AM, Iqbal M (2015) Chloroplast and photosystems: impact of cadmium and iron deficiency. Photosynthetica 53 (3): 321-335.

Bates LS, Walderen RD, Taere ID (1973). Rapid determination of free proline for water-stress studies. Plant Soil 39:205207.

Bohnert HJ, Nelson DE, Jensen RG (1995). Adaptations to environmental stresses. Plant Cell 7:1099-1111.

Bradford MM (1976). A rapid and sensitive method for the quantitation of microgram quantities of protein utilizing the principle of protein dyes binding. Analytical Biochemistry 72:248-254.

Brunet J, Repellin A, Varrault G, Terrync N, Zuily-Fodil Y (2008). Lead accumulation in the roots of grass pea (Lathyrussativus): A novel plant for phytoremediation systems? Comptes Rendus Biologies 331:859-864.

Chance M, Maehly AC (1955). Assay of catalases and peroxidases. Methods in Enzymology 2:764-817.

Chen J, Shafi M, Li S, Wang Y, Wu J, Ye Z, ... Liu D (2015). Copper induced oxidative stresses, antioxidant responses and phytoremediation potential of Moso bamboo (Phyllostachys pubescens). Scientific Reports 5:13554. 
Chen J, Shiyab S, Han FX, Monts DL, Waggoner AW, Su ZY (2009). Bioaccumulation and physiological effects of mercury in Pteris vittata and Nephrolepi sexaltata. Ecotoxicology 18:110-121.

Chigbo C, Batty L (2013). Effect of EDTA and citric acid on phytoremediation of Cr-B [a] P-co contaminated soil. Environmental Science and Pollution Research 20(12):8955-8963.

Dixit P, Mukherjee PK, Ramachandran V, Eapen S (2011). Glutathione transferase from Trichoderma virens enhances cadmium tolerance without enhancing its accumulation in transgenic Nicotiana tabacum. PLoS ONE 6:e16360.

Dong J, Wu FB, Zhang GP (2006). Influence of cadmium on antioxidant capacity and four microelement concentrations in tomato seedlings (Lycopersicon esculentum). Chemosphere 64:1659-1666.

Duruibe JO, Ogwuegbu MOC, Egwurugwu JN (2007). Heavy metal pollution and human biotoxic effects. International Journal of Physical Sciences 2(5):112-118.

Ehsan S, Ali S, Noureen S, Mehmood K, Farid M, Ishaque W, ... Rizwan M (2014) Citric acid assisted phytoremediation of Cd by Brassica napus L. Ecotoxicology and Environmental Safety 106:164-172.

Evangelou VP, Marsi M (2001). Composition and metal ion complexation behavior of humic fractions derived from corn tissue. Plant Soil 229:13-24.

Farid M, Ali S, Shakoor MB, Bharwana SA, Rizvi H, Ehsan S, ... Hannan F (2013). EDTA assisted phytoremediation of cadmium, lead and zinc. International Journal of Agronomy and Plant Production 4(11):2833-2846.

Feng-Tao LI, Jian-Min QI, Gao-Yang Z, Li-Hui L, Ping-Ping F, Fen TA, Jian-Tang XU (2013). Effect of cadmium stress on the growth antioxidative enzymes and lipid peroxidation in two kenaf (Hibiscus cannabinus L.) plant seedlings. Journal of Integrative Agriculture 12:610-620.

Gajewska E, Skłodowska M (2010). Differential effect of equal copper, cadmium and nickel concentration on biochemical reactions in wheat seedlings. Ecotoxicology and Environmental Safety 73(5):996-1003.

Gill SS, Tuteja N (2010). Reactive oxygen species and antioxidant machinery in abiotic stress tolerance in crop plants. Plant Physiology and Biochemistry 48:909-930.

Gallego SM, Pena LB, Barcia RA, Azpilicueta CE, Iannone MF, Rosales EP, ... Benavides MP (2012). Unravelling cadmium toxicity and tolerance in plants: insight into regulatory mechanisms. Environmental and Experimental Botany 83:33-46.

Ghori NH, Ghori T, Hayat MQ, Imadi SR, Gul A, Altay V, Ozturk M (2019). Heavy metal stress and responses in plants. International Journal of Environmental Science and Technology 16(3):1807-1828.

Habiba U, Ali S, Farid M, Sharkoor MB, Rizwan M, Ibrahim M, ... Ali B (2015). EDTA enhanced plant growth, antioxidant defense system, and phytoextraction of copper by Brassica napus L. Environmental Science and Pollution Research 22(2):1534-1544.

Hajiboland R, Rad SB, Barceló J, Poschenrieder C (2013). Mechanisms of aluminum-induced growth stimulation in tea (Camellia sinensis). Journal of Plant Nutrition and Soil Science 176:616-625.

Hakeem KR, Alharby HF, Rehman R (2019). Antioxidative defense mechanism against lead-induced phytotoxicity in Fagopyrum kashmirianum. Chemosphere 216:595-604.

Hakeem KR, Sabir M, Ozturk M, Mermut A (2015). Soil remediation and plants: prospects and challenges. Elsevier, London, pp 724 .

Hameed A, Qadri TN, Zaffar M, Siddiqi TO, Ozturk M, Altay V, Ahmad P (2017). Biochemical and nutritional responses of Abelmoschus esculentus L. exposed to mercury contamination. Feb-Fresenius Environmental Bulletin 26(10):5814-5823.

Han F, Shan XQ, Zhang J, Xie YN, Pei ZJ, Zhang SZ, ... Wen B (2005). Organic acids promote the uptake of lanthanum by barley roots. New Phytologist 165:481-492.

Hasan, MM, Uddin MN, Ara-Sharmeen IF, Alharby H, Alzahrani Y, Hakeem KR, Zhang L (2019). Assisting phytoremediation of heavy metals using chemical amendments. Plants 8(9):295.

Hayat S, Hayat Q, Alyemeni MN, Wani AS, Pichtel J, Ahmad A (2012). Role of proline under changing environments: a review. Plant Signaling \& Behavior 7(11):1456-1466.

Heath RL, Packer L (1968). Photo-peroxidation in isolated chloroplasts: I. Kinetics and stoichiometry of fatty acid peroxidation. Archives of Biochemistry and Biophysics 125:189-198.

Hoagland DR, Arnon DI (1950). The water-culture for growing plants without soil. Circular. California Agricultural Experiment Station 347(2):32. 
Hu R, Sunc K, Suc X, Pana Y, Zhanga Y, Wanga X (2012). Physiological responses and tolerance mechanisms to Pb in two xerophils: Salsolapasserina bunge and Chenopodium album L. Journal of Hazardous Materials 205(206):131-138.

Iqbal M, Ahmad A, Ansari MKA, Qureshi MI, Aref MI, Khan PR, ... Hakeem KR (2015). Improving the phytoextraction capacity of plants to scavenge metal(loid)-contaminated sites. Soil \& Environment 23(1): 44-65.

Jabeen R, Ahmad A, Iqbal M (2009). Phytoremediation of heavy metals: Physiological and molecular aspects. The Botanical Review 75:339-364.

Jaishankar M, Tseten T, Anbalagan N, Mathew BB, Beeregowda KN (2014). Toxicity, mechanism and health effects of some heavy metals. Interdisciplinary Toxicology 7(2):60-72.

Kambhampati MS (2013). EDTA enhanced phytoremediation of copper contaminated soils using chickpea (Cicera eritinum L.). Bulletin of Environmental Contamination and Toxicology 91(3):310-313.

Khudsar T, Iqbal M (2001). Cadmium-induced change in leaf epidermes, photosynthetic rate and pigment concentrations in Cajanus cajan. Biologia Plantarum 44:59-64.

Kupper H, Kupper F, Spiller M (1998). In situ detection of heavy metal substituted chlorophylls in water plants. Photosynthesis Research 58:123-133.

Lichtenthaler HK, Wellburn AR (1983). Determination of total carotenoids and chlorophylls a and b of leaf extracts in different solvents. Biochemical Society Transaction 11:591-603.

Liu D, Wang X, Chen Z, Xu H, Wang Y (2010). Influence of mercury on chlorophyll content in winter wheat and mercury bioaccumulation. Plant, Soil and Environment 56:139-143.

Ma MF, Zheng SJ, Hiradate S, Matsumoto H (1997). Detoxifying aluminum with buckwheat. Nature 390:569-570.

Malar S, Sahi SV, Favas PJC, Venkatachalam P (2015). Mercury heavy-metal-induced physiochemical changes and genotoxic alterations in water hyacinths [Eichhornia crassipes (Mart.)]. Environmental Science and Pollution Research 22:4597-4608.

Mani D, Kumar C, Patel NK (2014). Hyperaccumulator oilcake manure as an alternative for chelate-induced phytoremediation of heavy metals contaminated alluvial soils. International Journal of Phytoremediation 17(16):256-63.

Marschner H (1995). Mineral nutrition in higher plants. 2nd edn. Academic, London.

Marchiol L, Assolari S, Sacco P, Zerbi G (2004). Phytoextraction of heavy metals by canola (Brassica napus) and radish (Raphanus sativus). Environmental Pollution 132(1):21-27.

Nouri J, Lorestani B, Yousefi N, Khorasani N, Hasani AH, Seif S, Cheraghi M (2011). Phytoremediation potential of native plants grown in the vicinity of Ahangaran lead-zinc mine Hamedan, Iran. Environmental Earth Sciences 62(3):639-644.

Nor M, Cheng H (1986). Chemical speciation and bioavailability of Cu: uptake and accumulation by Eichornia. Environmental Toxicology and Chemistry: An International Journal 5:941-947.

Ozturk M (1989). Plants and pollutants in developed and developing countries. Ege Univ. Press, Izmir, pp 759.

Ozturk M, Ashraf M, Aksoy A, Ahmad MSA (2015a). Phytoremediation for green energy. Springer, New York.

Ozturk M, Ashraf M, Aksoy A, Hakeem KR, Ahmad MSA (2015b). Plants, pollutants and remediation. Springer, New York.

Ozturk M, Altay V, Karahan F (2017). Studies on trace elements in Glycyrrhiza taxa distributed in Hatay-Turkey. International Journal of Plant and Environment 3(2):01-07.

Pirzadah TB, Malik B, Tahir I, Kumar M, Varma A, Rehman RU (2014). Phytoremediation: an eco-friendly green technology for pollution prevention, control and remediation. In: Hakeem KR, Sabir M, Ozturk M, Mermut $\mathrm{AH}$ (Eds.). Soil remediation and plants: prospects and challenges. Elsevier publications, USA, pp 107-122.

Placek A, Grobelak A, Kacprzak M (2016). Improving the phytoremediation of heavy metals contaminated soil by use of sewage sludge. International Journal of Phytoremediation 18(6):605-618.

Plata JS, Villasante CO, Flores-C'aceres ML, Escobar C, del Campo FF, Hernandez LE (2009). Differential alterations of antioxidant defenses as bio-indicators of mercury and cadmium toxicity in Alfalfa. Chemosphere 77(7):946954.

Prasad DDK, Prasad ARK (1987). Altered $o$-aminolevulinic acid metabolism by lead and mercury in germination seedlings of bajra (Pennisetum typoideum). Journal of Plant Physiology 127:241-249.

Quartacci M, Pinzino C, Sgherri C, Dalla VF, Navari-Izz F (2000). Growth in excess copper induces changes in the lipid composition and fluidity of PS-II enriched membrane in wheat. Physiologia Plantarum 108(1):87-93. 
Qureshi MI, Israr M, Abdin MZ, Iqbal M (2005). Responses of Artemisia annua L. to lead and salt-induced oxidative stress. Environmental and Experimental Botany 53:185-193.

Qureshi MI, Abdin MZ, Qadir S, Iqbal M (2007). Lead-induced oxidative stress and metabolic alterations in Cassia angustifolia Vahl. Biologia Plantarum 51: 121-128.

Rastgoo L, Alemzadeh A (2011). Biochemical responses of Gouan (Aeluropus littoralis) to heavy metals stress. Australian Journal of Crop Science 5(4):375-383.

Rizwan M, Ali S, Adrees M, Rizvi H, Rehman MZ, Hannan F, ... Ok YS (2016). Cadmium stress in rice: toxic effects, tolerance mechanisms and management: A critical review. Environmental Science and Pollution Research 23(18):17859-17879.

Rosa M, Prado C, Podazza G, Interdonato R, González JA, Hilal M, Prado FE (2009). Soluble sugars-metabolism, sensing and abiotic stress: A complex network in the life of plants. Plant Signaling \& Behavior 4(5):388-393.

Sabir M, Waraich EA, Hakeem KR, Ozturk M, Ahmad HR, Shahid M (2015b). Phytoremediation: mechanisms and adaptations. In: Hakeem K, Sabir M, Ozturk M, Mermut A (eds). Soil remediation and plants: prospects and challenges. Elsevier, New York, pp 85-105.

Sahu, GK, Upadhyay S, Sahoo BB (2012) Mercury induced phytotoxicity and oxidative stress in wheat (Triticum aestivum L.) plants. Physiology and Molecular Biology of Plants 18(1):21-31.

Saifullah Khan MN, Iqbal M, Naeem A, Bibi S, Waraich EA, Dahlawi S (2016). Elemental sulfur improves growth and phytoremediative ability of wheat grown in lead-contaminated calcareous soil. International Journal of Phytoremediation 18:1022-1028.

Sarwar N, Imran M, Shaheen MR, Ishaque W, Kamran MA, Matloob A, ... Hussaine S (2017). Phytoremediation strategies for soils contaminated with heavy metals: Modifications and future perspectives. Chemosphere 710 721.

Saxena G, Purchase D, Mulla SI, Saratale GD, Bharagava RN (2019). Phytoremediation of heavy metal-contaminated sites: eco-environmental concerns, field studies, sustainability issues, and future prospects. In: de Voogt P (Eds.). Rev EnvContTox Vol 249. Reviews of Environmental Contamination and Toxicology (Continuation of Residue Reviews), vol 249. Springer, Cham.

Schützendübel A, Polle A (2002). Plant responses to abiotic stresses: heavy metal-induced oxidative stress and protection by mycorrhization. Journal of Experimental Botany 53:1351-1365.

Shu, X, Yin LY, Zhang QF, Wang WB (2015). Effect of Pb toxicity on leaf growth, antioxidant enzyme activities, and photosynthesis in cuttings and seedlings of Jatropha curcas L. Environmental Science and Pollution Research 19(3):893-902.

Singh J, Kalamdhad AS (2011). Effects of heavy metals on soil, plants, human health and aquatic life. International Journal of Research in Chemistry and Environment 1(2):15-21.

Souza LA, Piotto FA, Nogueirol RC, Azevedo RA (2013). Use of non-hyperaccumulator plant species for the phytoextraction of heavy metals using chelating agents. Scientia Agricola 70(4):290-295.

Szczygłowskan M, Piekarska A, Konieczka P, Namiesnik J (2011). Use of brassica plants in the phytoremediation and biofumigation processes. International Journal of Molecular Sciences 12:7760-7771.

Székely A, Balota DA, Duchek JM, Nemoda Z, Vereczkei A, SasvariSzekely M (2011). Genetic factors of reaction time performance: DRD4 7 repeat allele. Genes Brain and Behavior 10(2):129-136.

Wang Y, Li Y, Ma C, Qiu D (2016). Gas exchange, photosystem II photochemistry, and the antioxidant system of longan plant (Dimocarpus longan Lour.) leaves in response to lead (Pb) stress. Plant Omics 9(4):240-247.

Wilkins DA (1957). A technique for the measurement of Pb tolerance in plants. Nature 180:37-38.

Wirosoedarmo R, Anugroho F, Hanggara SD, Gustinasari K (2018). Effect of adding chelating agents on the absorption of zinc from polluted soil sludge textile industrial waste by sunflower plant (Helianthus annuus L.). Applied and Environmental Soil Science.

Yu CW, Murphy TH, Lin CH (2003). Hydrogen peroxide-induces chilling tolerance in mung beans mediated through ABA independent glutathione accumulation. Functional Plant Biology 30:955-963.

Zhang H, Li YH, Hu LY,Wang SH, Zhang FQ, Hu KD (2008). Effects of exogenous nitric oxide donor on antioxidant metabolism in wheat leaves under aluminum stress. Russian Journal of Plant Physiology 55:469-474.

Zhang Y, Xu S, Yang S, ChenY (2015). Salicylic acid alleviates cadmium-induced inhibition of growth and photosynthesis through upregulating antioxidant defense system in two melon cultivars (Cucumismelo L.). Protoplasma 252:911-924. 
OPEN ACCESS

(c) (i)

The journal offers free, immediate, and unrestricted access to peer-reviewed research and scholarly work. Users are allowed to read, download, copy, distribute, print, search, or link to the full texts of the articles, or use them for any other lawful purpose, without asking prior permission from the publisher or the author.

License - Articles published in Notulae Botanicae Horti Agrobotanici Cluj-Napoca are Open-Access, distributed under the terms and conditions of the Creative Commons Attribution (CC BY 4.0) License.

(c) Articles by the authors; UASVM, Cluj-Napoca, Romania. The journal allows the author(s) to hold the copyright/to retain publishing rights without restriction. 